[Note]

\title{
A Measurement of Body Volume of Mouse
}

\author{
Hiroshi UCHIDA and Akira MORI \\ Miyagi Agricultural College, Sendai \\ Nobuo GOTŌ \\ Aizu Junior College of Fukushima Prefecture, Aizu
}

(Accepted for publication: June 19, 1973)

This experiment, by the application of Boyle's law that the product of a given gas volume and its pressure are constant, aimed at contriving the apparatus for measuring body volume of mouse and investigating its accuracy, precision, and sensitivity. In this experiment we used a known volume of water $(5,10, \ldots \ldots, 50 \mathrm{ml})$ as our subject, and the result is as follows.

1) Every measuring value is about $1 \mathrm{~m} l$ more or less than the known value.

2) The coefficient of variation in every measuring value has a tendency to decrease as the subject volume increases.

3) To keep the sensitivity of the apparatus constant by using many kinds of subject volume, it is necessary to keep gas volume in the subject chamber constant by putting the object of the known volume besides the subject volume in the subject chamber. 〔Exp. Animals, 22 (3), 267$270,1973]$

マウ 内 体 積 測定方法
宮城県農業短期大学
後 藤 信 男
福島県立会津短期大学

動物体は，成長中，体重の増加ととも体積も増大して いるが, 体積の加令的変化について観察がほとんぞ行な われていない。これは，その測定方法が難しいからと思 われる。動物体の体積が生体で測定できるならば比重も 算出でき, 体重・体積・比重の加令的変化が把握される ことになり, 動物の体組成の推定, 栄養要求量の決定, 育種における選抜の指標などとして有効と思われる。

動物体の体積測定方法には, 液体置換法, 気体置換法 および写真測量法 [8]がある。これらのう.ち液体置換法 は, 動物体を液体に一定時間沈めるために動物に加わる ストレスが大きいので, 適当な方法とは思われない。こ れに反し，気体置換法は動物に加わるストレスが少ない ために,多くの研究者によって検討されている。Walser and Stein[10]は一定容積の試料容器に一定量のヘリウ ムガスを注入する装置を考案し, 次式からネコの体積を 測定している。

$$
\begin{aligned}
& \text { 動物の体積= }
\end{aligned}
$$

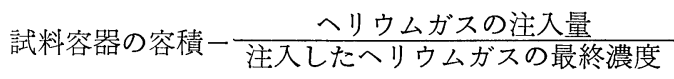$$
\text { しかし，最も多く行なわれている方法は，一定量の気 }
$$
体の圧力と体積の積は一定であるという関係を利用した 方法である[1,2,4,5]。たと党ば Loh[5]拈よび Hix ら 〔3〕は, 同一容積の容器を 2 個用意し, 一方には既知体 積の物体を, 他方には被検物体をいれて, 両容器を同一 のマノメーターに連結して両容器内の気体の圧力差から 体積を求める方法で，それぞれ人間および豚の体積を測 
定している。最近では, Purchas and Pearson[9]が, Loh[5]と Hix ら[3]の方法を改良し, その有效性を検 討している。

著者らは，上記諸氏らと同様に，気体の圧力と体積の 関係を利用した容積計を試作し, その正確度, 精度, 感 度なぞについてしらべ，本装置がマウスの体積測定に有 効であるか否かを検討した。

\section{材 料 と方 法}

材料：あらかじめ容積をホールピペットで測定した水

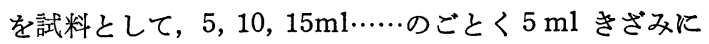
$50 \mathrm{ml}$ まで, 各容積について 5 回ずつ繰り返し測定した。

容積計：第 1 図のような容積計を試作した。本装置 は, ガラス器 $\mathrm{A}$ - B とCをユニ管で連結し水銀をいれた るのである。

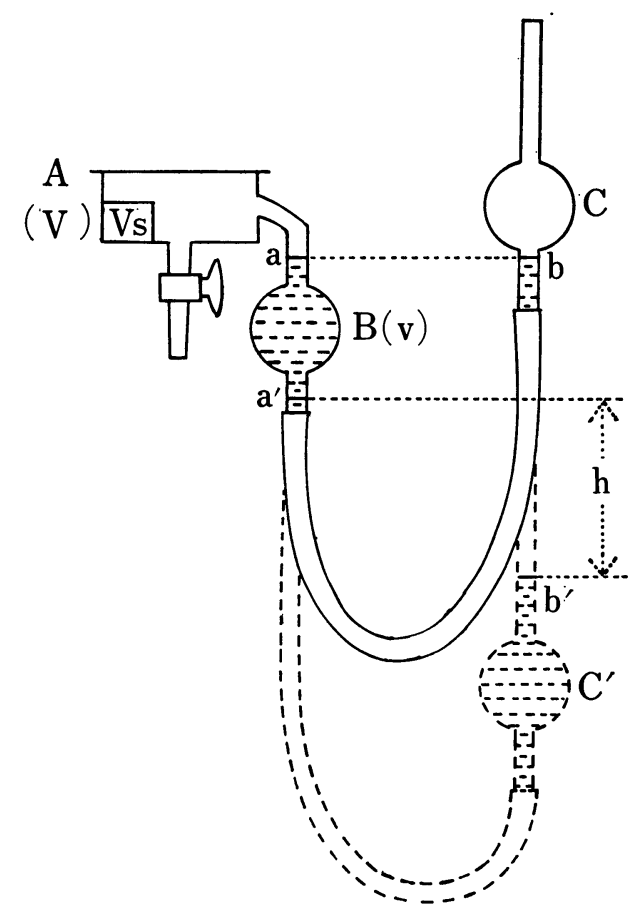

Fig. 1 Diagram of appartus for measuring body volume of mouse

測定方法：はじめに試料容器 $\mathrm{A}$ のなをとり，Cを上 下してBの水銀面が a にきたときにふたをする。そのま まCを $\mathrm{C}^{\prime}$ まで下げ $\mathrm{B}$ の水銀面が $\mathrm{a}^{\prime}$ にくるようにする が，このとき $\mathrm{C}^{\prime}$ 水銀面は $\mathrm{b}^{\prime}$ まできたるのとする。こ こでA内の空気の $\mathrm{a} よ り$ 上方の体積を $\mathrm{V}, \mathrm{a}$ と $\mathrm{a}^{\prime}$ の間の 体積を $\mathrm{v}$, 大気圧を水銀社 $\mathrm{Po}, \mathrm{a}^{\prime}$ と $\mathrm{b}^{\prime}$ との鉛直距離 をhとする。つぎに体積 Vs の被検物体を $\mathrm{A}$ 内に入れて 同様に操作し, $\mathrm{h}$ の值が $\mathrm{h}^{\prime}, \mathrm{V}$ の值が $\mathrm{V}^{\prime}$ になったとす ると Boyle の法則により次式がえられる。

$$
\begin{aligned}
& \mathrm{VPo}=(\mathrm{V}+\mathrm{v})(\mathrm{Po}-\mathrm{h}) \\
& \mathrm{V}^{\prime} \mathrm{Po}=\left(\mathrm{V}^{\prime}+\mathrm{v}\right)\left(\mathrm{Po}-\mathrm{h}^{\prime}\right)
\end{aligned}
$$

(1), (2) 式より

$$
\mathrm{Vs}=\mathrm{V}-\mathrm{V}^{\prime}=\mathrm{vPo}\left(\frac{1}{\mathrm{~h}}-\frac{1}{\mathrm{~h}^{\prime}}\right)
$$

\section{結 果 と考 察}

第 1 表は, 本装置を利用して被検物体(水)の各容積を 測定した結果を示したものである。なお，本装置のガラ ス器 $\mathrm{A}$ と $\mathrm{B}$ 容積はそれぞれ $\mathrm{V}=173.35 \mathrm{ml}, \mathrm{v}=50.90$

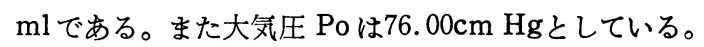

表から明らかなように, 各容積とも測定値が実容積 を $1 \mathrm{ml}$ 前後らわまわり, 標準偏差も $1 \mathrm{ml}$ 前後の值を示 している。変動係数は実容積の少ないものほど大きく， 容積の增加にともない減少する傾向がみられる。このよ らに，現段階では，本装置の正確度と精度は必らずしも 高いとはいえない。容積の測定值の誤差は，水銀面間の 鉛直距離の読みとり誤差, 温度, 気圧などの測定条件の 变化によると考えられる。たとえば，ここでは大気圧 Po $76.00 \mathrm{~cm} \mathrm{Hg}$ として測定值 Vsを算出している が，実験を行なった場所が海抜約 $100 \mathrm{~m}$ のところにあ り, 大気圧 $\mathrm{Po}$ は $76.00 \mathrm{~cm} \mathrm{Hg}$ 以下であることが推定 される。第 1 表のごとく, 測定值 Vs が実容積を $1 \mathrm{ml}$ 前後らわまわっているのは，このことが一因となってい ると考觉る。今後さらに, 正確度と精度を高めるには, 水銀がはいるガラス器の管の内径を細くしたり，水銀面 間の鉛直距離を測定するスケールの精度を高めたり，温 度や大気圧の変化を補正することなどが必要である。

つぎに， $\mathrm{v}$ とVの比率をかえたばあいの被検物体の単 位容積変化 $\mathrm{dVs}$ 当りの試料容器 $\mathrm{A}$ 内の圧力の変化 $\mathrm{d}\left(\mathrm{h}^{\prime}-\mathrm{h}\right)$, すなわち容積計の感度を検討し, その理論 值を求めた。その結果を試料容器 $\mathrm{A}$ 内の圧力 $\mathrm{Po}-\mathrm{h}^{\prime}$ と ともに第 2 表に示す。

容積計の感度は，(1)，(2) 式より次式のようになる。

$$
\frac{\mathrm{d}\left(\mathrm{h}^{\prime}-\mathrm{h}\right)}{\mathrm{dVs}}=\frac{\mathrm{Pov}}{(\mathrm{V}-\mathrm{Vs}+\mathrm{v})^{2}}
$$

ここでは,VsはV V の 20\%としている。表によれば $\frac{\mathrm{v}}{\mathrm{V}}=0.8$ のときに容積計の感度が最も高くなり，これ をさかいにして v：V比が開くにともない感度が低下す る。一方, 試料容器内の圧力は $\frac{\mathrm{v}}{\mathrm{V}}$ が小さくなるにした がって高くなる。

一般に, $\frac{\mathrm{v}}{\mathrm{V}}=\mathrm{m}, \frac{\mathrm{Vs}}{\mathrm{V}}=\mathrm{n}$ としたばあい,これらを 
Table 1. Means, standard deviations and coefficients of variation for every measuring value obtained by determination a) using the known volume of water

\begin{tabular}{c|ccc}
\hline $\begin{array}{c}\text { A known volume } \\
\text { of water } \\
(\mathrm{ml})\end{array}$ & Mean & $\begin{array}{c}\text { Standard } \\
\text { deviation } \\
(\mathrm{ml})\end{array}$ & $\begin{array}{c}\text { Coefficient } \\
\text { of variation } \\
(\%)\end{array}$ \\
\hline 5 & 5.60 & 1.14 & 20.36 \\
10 & 10.85 & 1.00 & 9.22 \\
15 & 16.21 & 0.74 & 4.57 \\
20 & 21.06 & 1.38 & 6.55 \\
25 & 26.56 & 1.95 & 7.34 \\
30 & 31.04 & 1.15 & 3.70 \\
35 & 36.21 & 1.36 & 3.76 \\
40 & 41.18 & 1.25 & 3.04 \\
45 & 46.22 & 1.35 & 2.92 \\
50 & 51.62 & 1.45 & 2.81 \\
\hline
\end{tabular}

a) Every determination is repeated 5 times.

Table 2. Change in sensitivity $\left[\frac{d\left(h^{\prime}-h\right)}{d V s}\right]$ and see copy subject chamber (Po $\left.-\mathrm{h}^{\prime}\right)$ with change in the ratio $\mathrm{v}$ : $\mathrm{V}$ when $\mathrm{Vs}=0.20 \mathrm{~V}$

\begin{tabular}{r|ll}
\hline \multicolumn{1}{c|}{$\frac{\mathrm{v}}{\mathrm{V}}$} & $\frac{\mathrm{d}\left(\mathrm{h}^{\prime}-\mathrm{h}\right)}{\mathrm{dVs}}$ & $\mathrm{Po}-\mathrm{h}^{\prime}$ \\
\hline 100.00 & $0.0098 \frac{\mathrm{Po}}{\mathrm{V}}$ & $0.0079 \mathrm{Po}$ \\
10.00 & 0.0857 & 0.0714 \\
5.00 & 0.1724 & 0.1379 \\
1.00 & 0.3086 & 0.4444 \\
0.80 & 0.3125 & 0.5000 \\
0.50 & 0.2959 & 0.6154 \\
0.10 & 0.1235 & 0.8889 \\
0.01 & 0.0152 & 0.9877 \\
0.00 & 0.0000 & 1.0000 \\
\hline
\end{tabular}

（4）式に代入すると, 容積計の感度 $\frac{\mathrm{d}\left(\mathrm{h}-\mathrm{h}^{\prime}\right)}{\mathrm{dVs}}$ はmの関 数として次式のように表わせる。

$$
f(\mathrm{~m})=\frac{\mathrm{mPo}}{(\mathrm{m}+1-\mathrm{n})^{2} \mathrm{~V}}
$$

(5) 式の一次導関数をとることにより, $f(\mathrm{~m})$ は $\mathrm{m}=$ 1 - $\mathrm{n}$ のとさ最大となることがわかる。第 2 表のばあ $\mathrm{n}=0.2$ であるから, $\mathrm{m}=0.8$ すなわち $\mathrm{v}$ が $\mathrm{V}$ の $80 \%$ の ときに容積計の感度が最高となる。一方, 最高感度を得 るときの $\mathrm{m} の$ 值は, 被検物体の試料容器 $\mathrm{A}$ 内に占める割

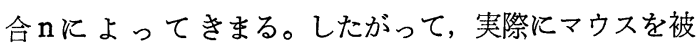
検物体とするばあい，その体積はさまざまであるので常 に最高に近い感度を得るためには, 試料容器 $\mathrm{A}$ 内に被検 マウスの他に既知体積の物体をいれるなどして試料容器 $\mathrm{A}$ 内の空気の体積 $\mathrm{V}^{\prime}$ がなるべく一定になるようにする
ことが必要である。また，最高感度では，第 2 表のよう に試料容器内の圧力 $\mathrm{Po}-\mathrm{h}^{\prime}$ は大気圧 $\mathrm{Po}$ の $1 / 2$ に減圧 するが，モルモット[4]拈よびラット[6,7]での減圧実験 の結果からみて，マウスでもこの程度の減圧は生体にさ ほどの生理的悪影響をおよぼさないと考えられる。

以上から, 本装置は操作がきわめて簡便であり, 今後 さらに測定の正確度, 精度および感度を高めるように改 良すれば，マウスの体積測定に有効であるといえる。

\section{要 約}

一定量の気体の圧力と体積の積は一定であるといら Boyleの法則を利用して, マウスの体積を測定する装置 を考案し, その正確度, 精度拈よび感度を検討した。試 料としては既知容積の水 $(5,10,15 \cdots \cdots, 50 \mathrm{ml})$ を用い た。1)実測值は, 各容積とも試料容積を $1 \mathrm{ml}$ 前後うわ まわっている。2)実測值の変動係数は, 試料容積が大に なるほど小になる傾向がみられる。3)種々容積の試料を 用いて一定の感度を得るには, 試料容器に試料の他に既 知体積の物体をいれるなどして, 試料容器内の気体の体 積をつねに一定にする必要がある。

\section{文献}

[1] Fomon, S. G., Jensen, R. L. and Owen, G. M. : Determination of body volume of infants by a method of helium displacement. Ann. N. Y. Acad. Sci., 110, 80-90 (1963).

[2] Gnaedinger, R. H., Reineke, E. P., Pearson, A. M., Van Huss, W. D., Wessel, J. A. and 
Montoye, H. J. : Determination of body density by air displacement, helium dilution, and underwater weighing. Ann. N. Y. Acad. Sci., 110, 96-108 (1963).

[3] Hix, V. M., Pearson, A. M., Reineke, E. P. and Gillett, T. A. : Determination of specific gravity of live hogs by suppressed zero techniques. J. Animal Sci., 26, 50-57 (1967).

[4] Liuzzo, J. A., Reineke, E. P. and Pearson, A. M. : Determination of specific gravity by air displacement. J. Animal Sci., 17, 513-520 (1958).

[5] Loh, Y.C. : Measurment of human body density. pp. 4-28, Ford Motor Company Sci. Lab. Rep., Dearborn, Michigan, U. S. A. (1 956).

〔6〕万木良平・飯塚道彦・秋山明子：Hypoxia によ
るラットの体温降下とガス代謝との 関係。J. J. Aerospace Med. \& Psy., 5, 29-36 (1968).

[7] よるラットの体温降下現象。航空医学実験報告, 9 (2), 100-107 (1968).

[8] Pierson, W. R. : A photogrammetric technique for the estimation of surface area and volume. Ann. N. Y. Acad. Sci., 109-112 (1963).

[9] Purchas, R. W. and Pearson, A. M. : A comparison of two system for measuring volume by air displacement. J. Animal Sci., 33, 1237-1241 (1971).

[10] Walser, M. and Stein, S. N. : Determination of specific gravity of intact animals by helium displacement ; compasison with water displacement. Proc. Soc. Exp. Biol. Med. 82, 774-777 (1953). 